\title{
PEMBUATAN BAKTO AGAR DARI RUMPUT LAUT Gelidium rigidum UNTUK MEDIA TUMBUH BAGI MIKROORGANISME
}

\author{
Murdinah*), Dina Fransiska*), dan Subaryono*)
}

\begin{abstract}
ABSTRAK
Telah dilakukan penelitian tentang pembuatan bakto agar dari rumput laut Gelidium rigidum untuk media tumbuh bagi mikroorganisme. Pembuatan bakto agar dilakukan dengan variasi waktu ekstraksi yaitu 1, 2, dan 3 jam pada suhu $121^{\circ} \mathrm{C}$ dan tekanan $1,1 \mathrm{~atm}$. Bakto agar dianalisis rendemen dan mutunya yang meliputi kadar air, kadar abu, kadar abu tak larut asam, kadar sulfat, kekuatan gel, $\mathrm{pH}$, titik leleh, dan titik jendal. Uji mikrobiologi yang diamati meliputi angka lempeng total bakteri (ALT) dan diameter koloni. Dari hasil pengamatan diketahui bahwa bakto agar hasil ekstraksi dari rumput laut jenis Gelidium rigidum selama 2 jam mutunya menyamai bakto agar komersial, khususnya dari nilai kadar air, pH, kadar abu, kadar abu tak larut asam, kekuatan gel, serta kemampuannya menumbuhkan bakteri yang terdapat pada ikan segar dan kultur murni yaitu E. coli dan L. lactis. Tetapi dalam hal kadar sulfat, titik leleh, dan titik jendal masih di bawah mutu bakto agar komersial. Hasil penelitian juga menunjukkan bahwa waktu ekstraksi selama 2 jam menghasilkan bakto agar yang memenuhi standar bakto agar komersial dengan karakteristik kadar air 10,41\%, kadar abu 2,1\%, kadar abu tak larut asam 0,18\%, kekuatan gel $670,72 \mathrm{~g} / \mathrm{cm}^{2}$, dan $\mathrm{pH} 7,1$.
\end{abstract} ABSTRACT: $\begin{aligned} & \text { Production of bacto agar from Gelidium rigidum as a growth media for } \\ & \text { microorganism. By: Murdinah, Dina Fransiska, and Subaryono }\end{aligned}$

Experiment on production of bacto agar from Gelidium rigidum as a growth media for microorganism had been conducted. The extraction was carried out at $121^{\circ} \mathrm{C}, 1.1 \mathrm{~atm}$ pressure for 1, 2, and 3 hours. The yield and quality of bacto agar that includes moisture, ash, acid insoluble ash, sulphate, gel strength, $\mathrm{pH}$, melting point, and gelling point was being analized. The microbiological parameters observed were total plate count (TPC) and colony diameters. Results indicated that bacto agar extracted from seaweed for 2 hours met the standard of commercial bacto agar, especially the moisture content, $\mathrm{pH}$, ash, acid insoluble ash, gel strength, the ability to grow bacteria contained in fresh fish as well as pure cultures of $\boldsymbol{E}$. coli and $\mathbf{L}$. lactis. However, the sulphate content, melting and gelling point do not met the prevailing standards. The results also showed that extraction for 2 hours produced bacto agar which has the same performance as commercial bacto agar with $10.41 \%$ moisture, $2.1 \%$ ash, $0.18 \%$ acid insoluble ash, $670.72 \mathrm{~g} / \mathrm{cm}^{2}$ gel strength, and $7.1 \mathrm{pH}$ value.

KEYWORDS: bacto agar, extraction time, Gelidium rigidum, microbiological media

\section{PENDAHULUAN}

Bakto agar adalah agar-agar yang telah dimurnikan dengan cara mereduksi serendah mungkin zat asing, pigmen pengotor, dan garam, yang secara khusus digunakan sebagai media kultur mikrobiologi. Bakto agar mempunyai bentuk granul yang halus dan menghasilkan larutan yang jernih (Anon., 2007a). Bakto agar biasanya digunakan dengan konsentrasi $1-2 \%$ dalam media kultur padat atau $0,05-0,5 \%$ untuk menentukan mobilitas dan pertumbuhan bakteri anaerobik dan mikroaerofilik (Selby \& Wynne, 1973).

Agar adalah pikokoloid yang diekstrak dari rumput laut merah (kelas Rhodophyceae) yang meliputi Gelidium, Pterocladia, dan Gracilaria. Gelidium merupakan sumber bahan baku yang lebih disukai untuk ekstraksi agar karena kekuatan gel yang dihasilkan relatif tinggi dengan kadar sulfat yang rendah (Anon., 2007b). Agar pertama kali dianjurkan untuk digunakan dalam media tumbuh bagi mikroorganisme pada tahun 1881 oleh Fannie Hesse (Anon., 2007a).

Beberapa jenis rumput laut penghasil agar di Indonesia adalah Gelidium rigidum, Rhodymenia ciliata, Gelidiella sp., dan Gracilaria sp. Selama ini pemanfaatan Gelidium rigidum sebagian besar masih diekspor dalam bentuk rumput laut kering atau sebagai campuran bahan baku industri agar di dalam negeri. Penggunaan Gelidium rigidum sebagai bahan baku utama industri pengolahan agar di dalam negeri umumnya masih kalah dibanding jenis lain seperti Gracilaria sp. karena kualitasnya yang rendah. Hal tersebut disebabkan karena tingginya tingkat bahan pengotor, banyaknya rumput laut lain sebagai

*) Peneliti pada Balai Besar Riset Pengolahan Produk dan Bioteknologi Kelautan dan Perikanan, DKP 
pencampur, serta teknologi ekstraksinya yang lebih sulit. Meskipun demikian rumput laut ini memiliki potensi sebagai penghasil agarose yang bernilai tinggi, sehingga permintaan dunia akan rumput laut ini relatif tinggi. Di beberapa negara maju jenis rumput laut ini digunakan sebagai bahan baku untuk industri agarose yang banyak digunakan dalam bidang bioteknologi seperti: gel elektroforesis, imunologi, media kultur mikroorganime, kolom kromatografi, teknik imobilisasi enzim, dan lain-lain (Murdinah et al., 2006).

Hasil penelitian tentang ekstraksi agar yang telah dilakukan umumnya baru menghasilkan agar kualitas pangan dan belum memenuhi kriteria sebagai bakto agar, karena rendahnya kekuatan gel, tingginya kadar abu dan abu tak larut asam (Utomo et al., 1990, Suryaningrum et al., 1994).

Jenis rumput laut yang digunakan dalam penelitian ini adalah Gelidium rigidum, mengingat pemanfaatan rumput laut ini masih sangat terbatas dan masih diekspor dalam bentuk rumput laut kering. Kebutuhan bakto agar masih sepenuhnya mengandalkan dari impor, meskipun produksi rumput laut penghasil agar di dalam negeri cukup tinggi. Harga bakto agar impor dengan kemasan 1 pound mencapai 157.55 US dolar setara dengan Rp. 1.570.000,- (Anon., 2007a). Apabila pembuatan bakto agar dapat dikembangkan di dalam negeri diharapkan akan diperoleh bakto agar yang harganya relatif lebih murah dari harga impor.

Tujuan dari penelitian ini adalah mempelajari pembuatan bakto agar dari rumput laut Gelidium rigidum untuk media tumbuh bagi mikroorganisme sehingga dapat menghasilkan bakto agar dengan kualitas yang memenuhi standar bakto agar komersial.

\section{BAHAN DAN METODE}

\section{Bahan}

Bahan baku yang digunakan dalam penelitian ini adalah rumput laut jenis Gelidium rigidum asal Wonosari, Kabupaten Gunung Kidul, Daerah Istimewa Yogyakarta.

Bahan kimia yang digunakan adalah larutan $\mathrm{NaOCl}$, dan isopropil alkohol (IPA). Alat yang digunakan antara lain gelas beker, gelas ukur, autoclave, termometer, pengaduk magnetik, dan oven.

\section{Metode}

Rumput laut jenis Gelidium rigidum disortasi dari jenis rumput laut lain, karang, pasir, kotoran, dan lainlain. Rumput laut yang telah disortasi kemudian dicuci dengan menggunakan air bersih hingga bebas dari kotoran yang menempel, kemudian dijemur di atas tanah yang diberi alas waring hingga kering. Bahan baku yang telah kering lalu dikemas dengan menggunakan karung plastik dan dibawa ke Laboratorium Pengolahan, Balai Besar Riset Pengolahan Produk dan Bioteknologi Kelautan dan Perikanan.

Sebanyak $10 \mathrm{~kg}$ bahan baku direndam dalam $60 \mathrm{~L}$ larutan $2 \% \mathrm{NaOCl}$ teknis selama 15 menit, selanjutnya dicuci dengan $198 \mathrm{~L}$ air dalam mesin pencuci (mollen) selama 15 menit. Perlakuan ini diulang sampai 4 kali. Rumput laut yang telah dicuci kemudian dijemur selama 12 jam di bawah sinar matahari dan menjadi bahan baku yang siap diekstrak untuk kegiatan penelitian.

Rumput laut Gelidium rigidum kering tersebut kemudian direndam dalam air bersih selama 1 jam (perbandingan rumput laut dan air $=1: 30$ ). Setelah itu diekstraksi menggunakan autoclave pada suhu $121^{\circ} \mathrm{C}$ dan tekanan $1,1 \mathrm{~atm}$ dengan perlakuan waktu ekstraksi 1, 2, dan 3 jam. Perbandingan rumput laut kering dengan volume air pengekstrak adalah $1: 30$. Rumput laut yang telah diekstraksi disaring menggunakan alat penyaring bergetar (vibrator screen) ukuran 300 mesh. Filtrat yang diperoleh dituang ke dalam bak kecil berukuran $25 \times 30 \times 7,5 \mathrm{~cm}$ dan dijendalkan pada suhu kamar selama 1 malam. Filtrat yang telah menjendal kemudian disimpan pada suhu $-17^{\circ} \mathrm{C}$ di cold storage selama 1 malam. Tahap selanjutnya yaitu pelelehan gel bakto agar dengan air sehingga serat bakto agar terpisah dari airnya. Serat bakto agar dilarutkan kembali dengan air (serat bakto agar : air = 1:50) dan direbus selama 2 jam sampai semua serat bakto agar larut sempurna. Serat bakto agar yang telah dilarutkan dijendalkan kembali pada suhu ruang selama 1 malam, kemudian dilelehkan dengan merendamnya di dalam air pada suhu kamar. Serat yang dihasilkan direndam dalam larutan isopropil alkohol teknis (serat : IPA = $1: 2$ ) selama 15 menit untuk menarik air, kemudian dikeringkan dengan oven pada suhu $50^{\circ} \mathrm{C}$ selama 1 malam dan digiling sehingga di peroleh tepung bakto agar. Ekstraksi bakto agar dilakukan seperti diagram alir pada Gambar 1 .

Penelitian ini dirancang menggunakan rancangan acak lengkap 3 kali ulangan. Beberapa pengamatan yang dilakukan adalah rendemen bakto agar, kadar air, dan kadar abu (AOAC, 1984), kadar abu tak larut asam (AOAC, 1984), kekuatan gel menggunakan texture analyzer TA XTPlus, kadar sulfat dengan metode gravimetri (Anon., 1991), titik leleh, dan titik jendal (Stanley, 1987).

Analisis mikrobiologi dilakukan dengan uji kuantitatif Angka Lempeng Total (ALT) pada bakto agar yang terpilih dengan dibandingkan bakto agar komersial untuk menumbuhkan bakteri yang terdapat pada ikan segar, kultur murni E. coli (mewakili Gram 


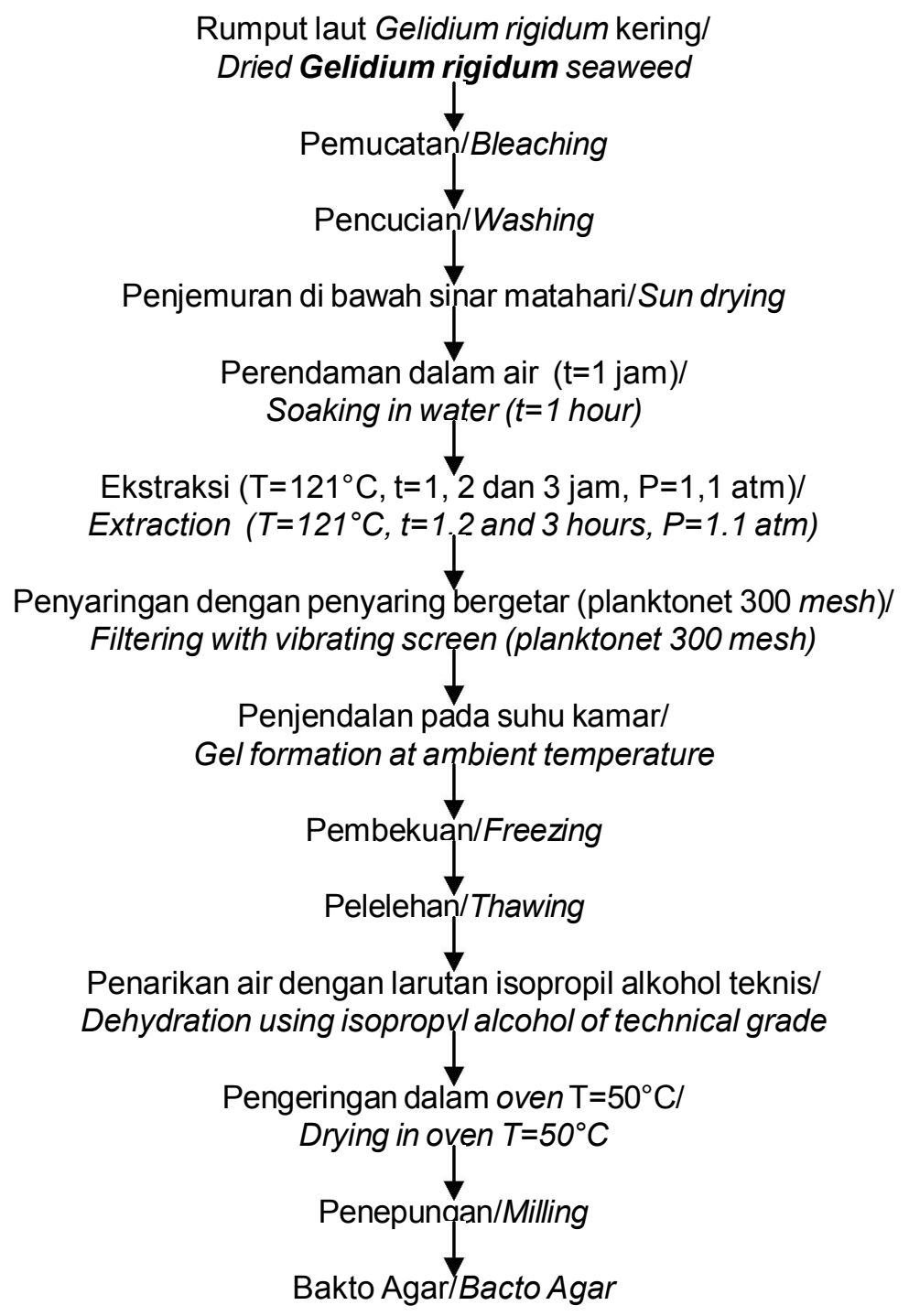

Gambar 1. Diagram alir ekstraksi bakto agar dari Gelidium rigidum.

Figure 1. Flow chart of bacto agar extraction from Gelidium rigidum.

negatif) dan kultur murni L. lactis (mewakili Gram positif). Pengujian dilakukan dengan cara menumbuhkan uji pada media padat dengan teknik agar sebar. Koloni yang tumbuh kemudian dihitung berdasarkan SNI (2006). Data diolah secara statistik dan dilanjutkan dengan uji lanjut beda nyata jujur (Steel \& Torrie, 1993).

\section{HASIL DAN BAHASAN}

\section{Rendemen}

Rendemen merupakan salah satu parameter yang penting dalam menilai efektif atau tidaknya suatu proses produksi. Rendemen suatu bahan pangan berhubungan dengan nilai ekonomis bahan tersebut. Semakin tinggi rendemen suatu produk, maka nilai ekonomisnya juga semakin tinggi. Nilai rendemen bakto agar dihitung berdasarkan perbandingan berat bakto agar yang dihasilkan terhadap berat kering rumput laut. Nilai rendemen yang dihasilkan berkisar antara 8,29-13,20\%.

Nilai rata-rata rendemen bakto agar yang dihasilkan dapat dilihat pada Gambar 2.

Hasil analisis statistik terhadap rendemen menunjukkan bahwa perlakuan berpengaruh nyata terhadap besarnya rendemen yang dihasilkan. Waktu ekstraksi selama 1 jam menghasilkan rendemen bakto agar yang berbeda nyata dengan ekstraksi selama 2 dan 3 jam sedangkan waktu ekstraksi 2 dan 3 jam tidak menunjukkan pengaruh yang nyata terhadap rendemen bakto agar. Rendemen bakto agar yang dibuat dengan waktu ekstraksi 1 jam adalah 8,29\%, waktu ekstraksi 2 jam adalah 12,33\%, dan waktu ekstraksi 3 jam adalah 13,20\%. Dari Gambar 2 


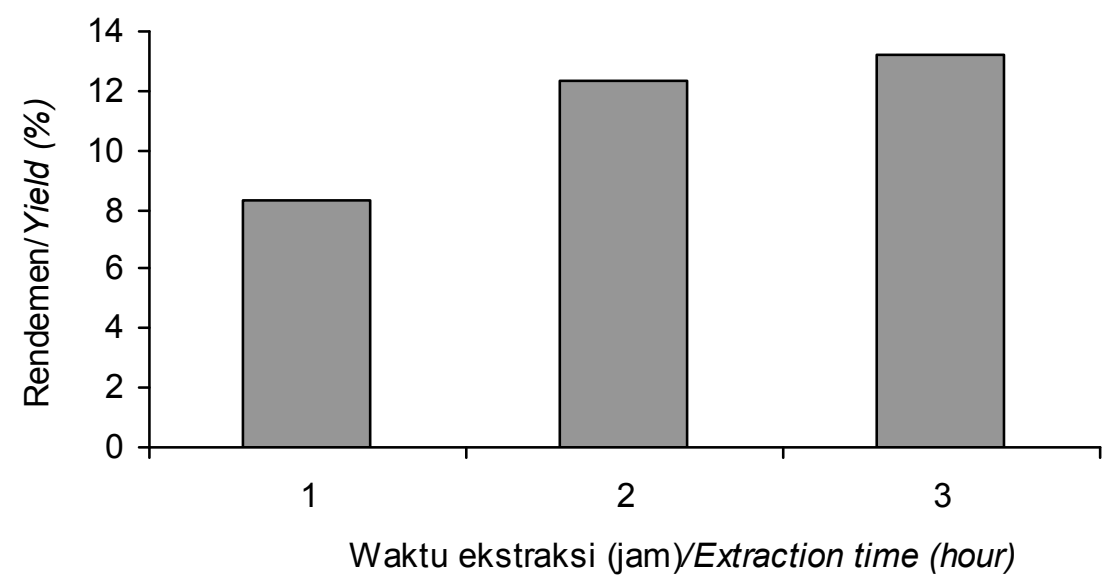

Gambar 2. Pengaruh waktu ekstraksi terhadap rendemen bakto agar.

Figure 2. Effect of extraction time on the yield of bacto agar.

terlihat bahwa ekstraksi bakto agar selama 1 jam menghasilkan rendemen yang kecil, hal ini disebabkan dalam 1 jam kandungan agar dalam rumput laut Gelidium rigidum belum terekstrak maksimal, sedangkan waktu ekstraksi yang lebih lama akan menyebabkan bakto agar yang terkandung dalam rumput laut lebih banyak terekstrak.

\section{Karakteristik Mutu Bakto Agar Komersial}

Berdasarkan standar supreme marine chemical, spesifikasi bakto agar komersial yang meliputi kadar air, kadar abu, kadar abu tak larut asam, kekuatan gel, $\mathrm{pH}$, titik leleh, dan titik jendal terlihat seperti pada Tabel 1 sedangkan kadar sulfat pada bakto agar komersial tidak boleh lebih dari 1,78\% (Anon., 2007b).

\section{Karakteristik Mutu Bakto Agar Hasil Ekstraksi}

\section{Kadar air}

Kadar air bakto agar yang dihasilkan untuk masingmasing perlakuan adalah berkisar antara 10,34-
10,95\% (Gambar 3). Perlakuan waktu ekstraksi tidak berpengaruh nyata terhadap kadar air bakto agar. Hal ini dikarenakan proses pengeringan bakto agar untuk semua perlakuan adalah sama yaitu oven pada suhu $50^{\circ} \mathrm{C}$ dengan waktu pengeringan selama 24 jam. Apabila dibandingkan dengan bakto agar komersial maka kadar air bakto agar dalam penelitian ini telah memenuhi standar spesifikasi bakto agar komersial dengan grade standar yaitu kadar air maksimal $12 \%$.

\section{Kadar abu}

Tujuan utama dari analisis kadar abu adalah untuk mengetahui secara umum kandungan mineral yang terdapat dalam bahan. Apriyantono et al. (1989) menyatakan bahwa nilai kadar abu suatu bahan pangan menunjukkan besarnya jumlah mineral yang terkandung dalam bahan pangan tersebut.

Kadar abu bakto agar berkisar antara 2,10-3,68\% (Gambar 4). Dengan demikian berdasarkan kadar abu, bakto agar yang dihasilkan telah memenuhi standar supreme marine chemical yaitu kadar abu maksimal $4 \%$. Kadar abu bakto agar tidak boleh lebih besar

Tabel 1. Spesifikasi bakto agar komersial (standar supreme marine chemical)

Table 1. Specification of commercial bacto agar (supreme marine chemical standard)

\begin{tabular}{lccc}
\hline \multicolumn{1}{c}{ Parameter/Parameters } & $\begin{array}{c}\text { Regulerl } \\
\text { Regular }\end{array}$ & $\begin{array}{c}\text { Standarl } \\
\text { Standard }\end{array}$ & $\begin{array}{c}\text { Premium/ } \\
\text { Premium }\end{array}$ \\
\hline Kadar air/Moisture content $(\%)$ & $<15.0$ & $<12.0$ & $<9.0$ \\
Kadar abu/Ash content $(\%)$ & $<4.5$ & $<4.0$ & $<1.0$ \\
Kadar abu tak larut asam/Acid insoluble ash $(\%)$ & $<1.0$ & $<1.0$ & $<1.0$ \\
Kekuatan gel/Gel strength $\left(\mathrm{g} / \mathrm{cm}^{2}\right)$ & $400.0-500.0$ & $500.0-650.0$ & $>650.0$ \\
$\mathrm{pH}$ & $7.0-7.5$ & $6.8-7.5$ & $6.8-7.5$ \\
Titik leleh/Melting temperature $\left({ }^{\circ} \mathrm{C}\right)$ & $78.0-80.0$ & $78.0-80.0$ & $78.0-80.0$ \\
Titik jendal/Gelling temperature $\left({ }^{\circ} \mathrm{C}\right)$ & $38.0-40.0$ & $38.0-40.0$ & $39.0-41.0$ \\
\hline
\end{tabular}

Sumber/Sources: Anon. (2004) 


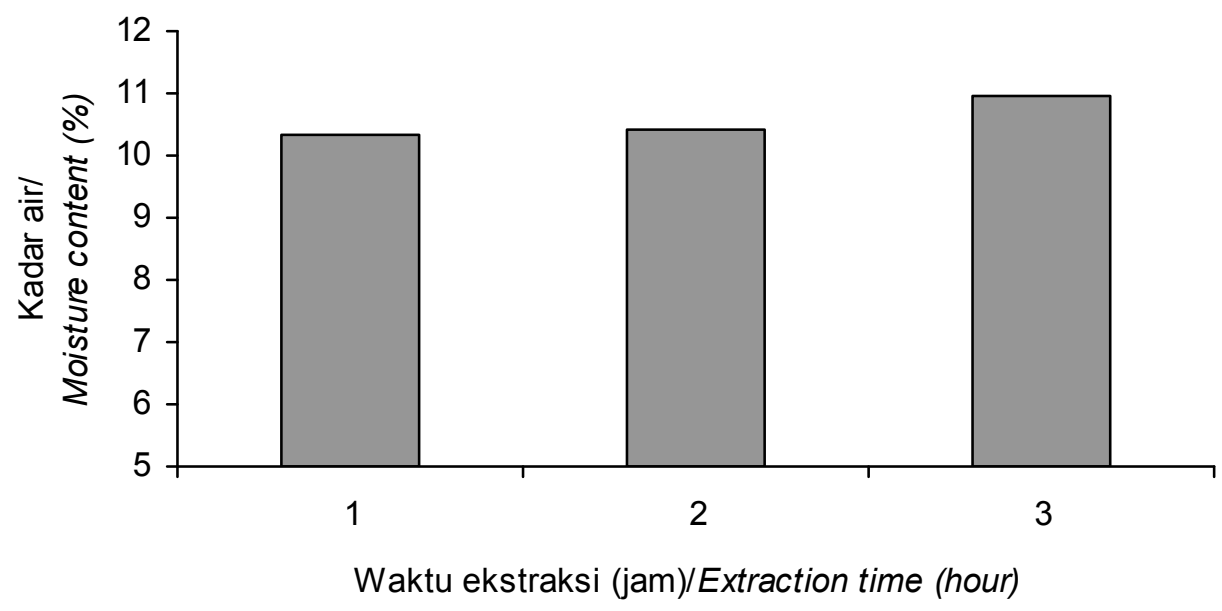

Gambar 3. Pengaruh waktu ekstraksi terhadap kadar air bakto agar.

Figure 3. Effect of extraction time on the moisture content of bacto agar.

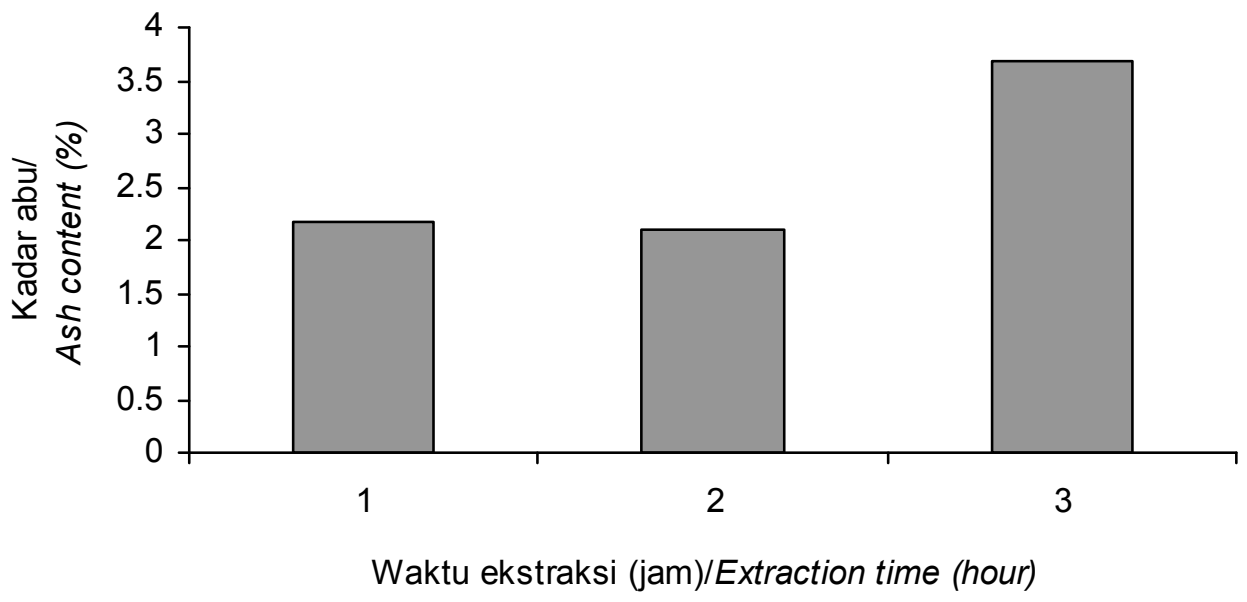

Gambar 4. Pengaruh waktu ekstraksi terhadap kadar abu bakto agar.

Figure 4. Effect of extraction time on the ash content of bacto agar.

dari standar, karena nilai kadar abu yang berlebihan dapat menghambat bakteri yang ditumbuhkan pada media tersebut.

Perlakuan waktu ekstraksi berpengaruh nyata terhadap kadar abu bakto agar. Waktu ekstraksi selama 3 jam memberikan perbedaan yang nyata terhadap kadar abu bakto agar yang dihasilkan dari waktu ekstraksi 1 dan 2 jam tetapi waktu ekstraksi 1 dan 2 jam tidak berpengaruh nyata. Kadar abu bakto agar dengan waktu ekstraksi 3 jam lebih tinggi dibandingkan kadar abu bakto agar yang diekstraksi 1 dan 2 jam. Hal ini dikarenakan pada waktu ekstraksi selama 3 jam, lebih banyak kandungan mineral dalam rumput laut yang terekstrak.

\section{Kadar abu tak larut asam}

Menurut Basmal et al. (2003) kadar abu tak larut asam adalah salah satu kriteria untuk menentukan tingkat kebersihan dalam proses pengolahan dan dicerminkan oleh adanya kontaminasi logam berat yang tidak larut asam dalam suatu produk. Kadar abu tak larut asam bakto agar pada penelitian ini adalah 0,18-0,38\%. Kadar abu tak larut asam bakto agar telah memenuhi standar supreme marine chemical dengan grade standar yaitu kurang dari $1 \%$. Rendahnya kadar abu tak larut asam pada penelitian ini menunjukkan rendahnya kontaminasi logam berat pada bakto agar yang dihasilkan. Kadar abu tak larut asam bakto agar yang dihasilkan dapat dilihat pada Gambar 5.

Semua perlakuan waktu ekstraksi berpengaruh nyata terhadap kadar abu tak larut asam bakto agar. Waktu ekstraksi selama 2 jam menghasilkan kadar abu tak larut asam yang lebih rendah dari waktu ekstraksi selama 1 dan 3 jam. 


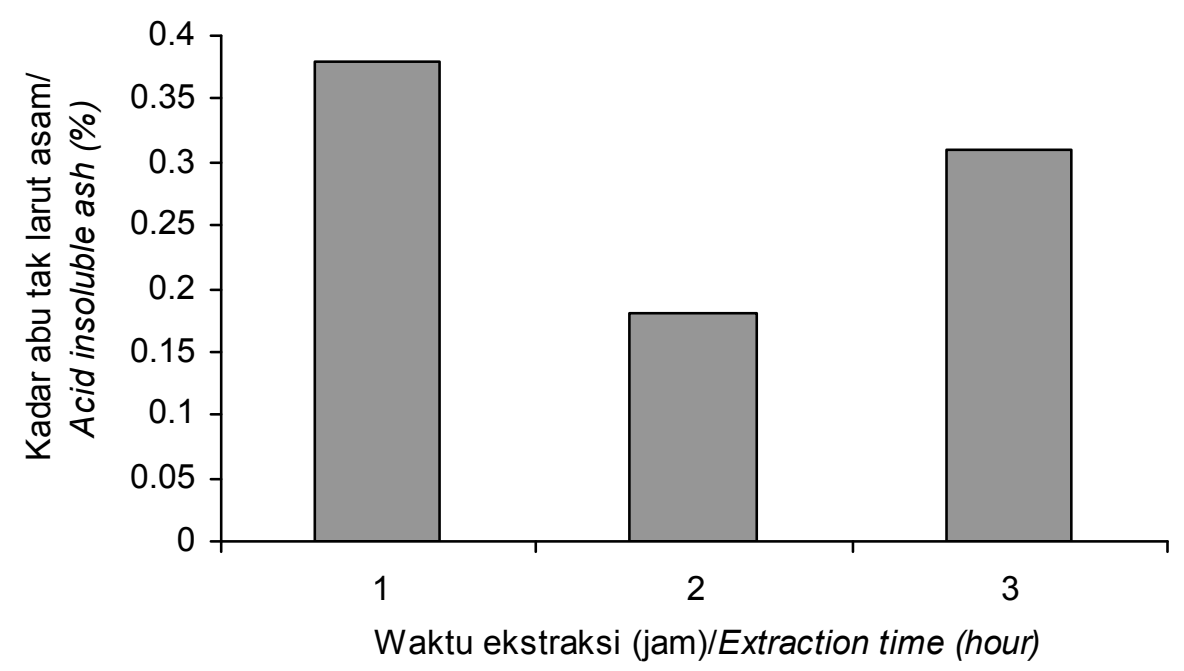

Gambar 5. Pengaruh waktu ekstraksi terhadap kadar abu tak larut asam bakto agar.

Figure 5. Effect of extraction time on the acid insoluble ash content of bacto agar.

\section{Kadar sulfat}

Kadar sulfat yang dihasilkan adalah 3,6-3,98\%. Kadar sulfat bakto agar yang dihasilkan terlihat pada Gambar 6.

Perlakuan waktu ekstraksi tidak berpengaruh nyata terhadap kadar sulfat bakto agar. Kadar sulfat dalam penelitian ini lebih tinggi dari kadar sulfat bakto agar komersial yang seharusnya 1,78\% (Anon., 2007b). Tingginya kadar sulfat ini diduga karena masih adanya ester sulfat pada C6 rantai galaktosa. Menurut Amnidar (1989), proses perlakuan dengan alkali dapat menghilangkan ester sulfat pada C6 rantai galaktosa karena alkali bereaksi dengan ester sulfat dan membentuk garam sulfat. Pada proses pembuatan bakto agar dilakukan penambahan alkali sehingga kadar sulfatnya menjadi rendah karena penambahan alkali dapat menghilangkan atau mengurangi kadar ester sulfat pada C6 rantai galaktosa, sedangkan pada penelitian ini tidak dilakukan penambahan alkali. Berdasarkan penelitian Murdinah et al. (2006), penambahan alkali yang berlebihan akan menghasilkan rendemen yang sangat kecil dan kenampakan produk yang tidak menarik (produk menjadi kehitam-hitaman).

\section{Kekuatan gel}

Kekuatan gel bakto agar yang dihasilkan berkisar antara $115,8-670,72 \mathrm{~g} / \mathrm{cm}^{2}$. Kekuatan gel tertinggi diperoleh dari proses ekstraksi selama 2 jam yaitu sebesar $670,72 \mathrm{~g} / \mathrm{cm}^{2}$ dan kekuatan gel terendah diperoleh dari proses ekstraksi selama 1 jam yaitu

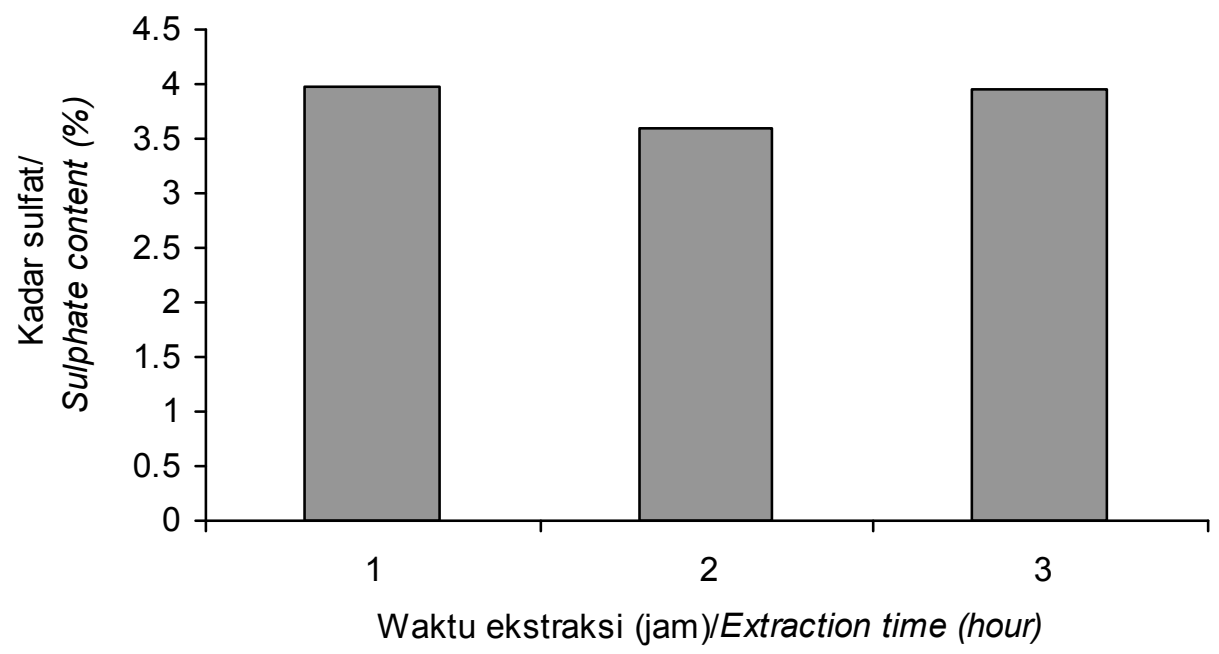

Gambar 6. Pengaruh waktu ekstraksi terhadap kadar sulfat bakto agar. Figure 6. Effect of extraction time on the sulphate content of bacto agar. 


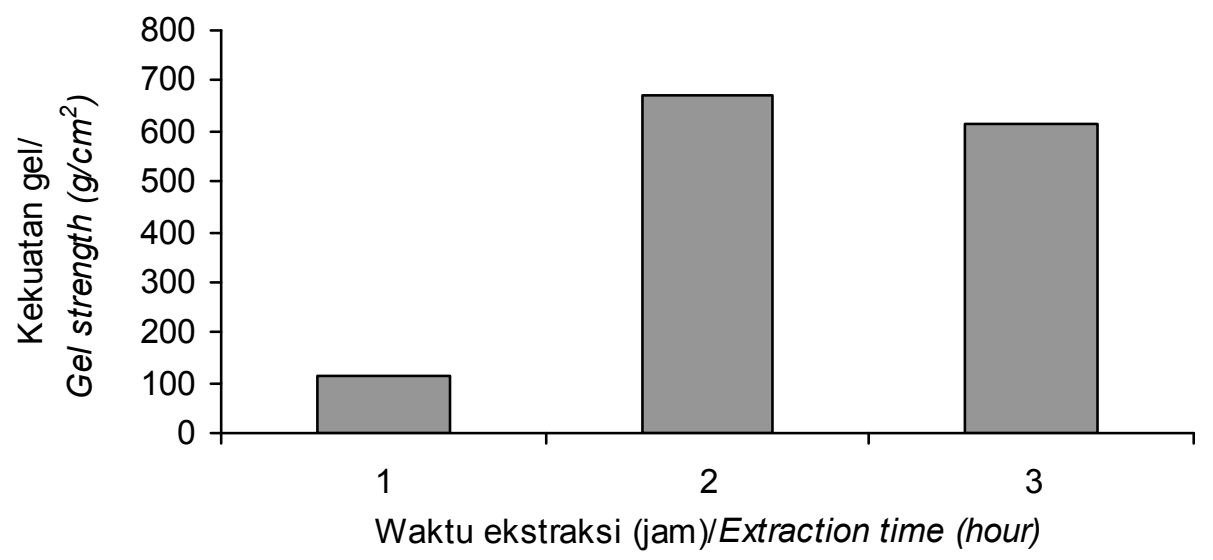

Gambar 7. Pengaruh waktu ekstraksi terhadap kekuatan gel bakto agar.

Figure 7. Effect of extraction time on the gel strength of bacto agar.

sebesar $115,80 \mathrm{~g} / \mathrm{cm}^{2}$. Kekuatan gel bakto agar yang dihasilkan dapat dilihat pada Gambar 7.

Semua perlakuan waktu ekstraksi berpengaruh nyata terhadap kekuatan gel bakto agar. Waktu ekstraksi 1 jam menghasilkan kekuatan gel yang rendah karena belum semua agar yang terkandung dalam rumput laut terekstrak, sedangkan pada waktu ekstraksi selama 2 jam menghasilkan kekuatan gel yang memenuhi standar bakto agar komersial dengan grade premium dan pada waktu ekstraksi selama 3 jam menghasilkan kekuatan gel yang memenuhi standar bakto agar komersial dengan grade standar.

Menurut Glicksman (1983) terdapat hubungan antara kadar sulfat yang dihasilkan dengan kekuatan gel dari bakto agar. Semakin tinggi kadar sulfat maka kekuatan gel akan semakin kecil. Hal ini karena ester sulfat pada atom karbon keenam dari L-galaktosa (C6) menyebabkan rantai polimer membentuk suatu tekukan yang dapat menghambat proses pembentukan gel.
Karakteristik pembentukan gel agar-agar disebabkan oleh tiga buah atom $\mathrm{H}$ pada residu 3,6 anhidro-L-galaktosa yang memaksa molekul-molekul untuk membentuk struktur heliks. Interaksi antar struktur heliks menyebabkan terbentuknya gel. Pergantian senyawa 3,6 anhidro-L-galaktosa oleh senyawa L-galaktosa sulfat menyebabkan kekacauan dalam struktur heliks dan dalam keadaan seperti ini kekuatan gel menjadi menurun. Adanya 3,6 anhidrogalaktosa akan menyebabkan sifat anhidrofilik dan meningkatkan pembentukan heliks rangkap sehingga terbentuk gel yang kuat (Stanley, 1987).

Nilai kekuatan gel bakto agar dengan waktu ekstraksi 2 jam telah masuk dalam grade gel strength premium untuk standar bakto agar, dengan nilai minimal untuk grade premium adalah $650 \mathrm{~g} / \mathrm{cm}^{2}$.

\section{pH}

Nilai $\mathrm{pH}$ bakto agar yang diperoleh dari hasil penelitian ini adalah 6,65-7,10 (Gambar 8). Nilai pH

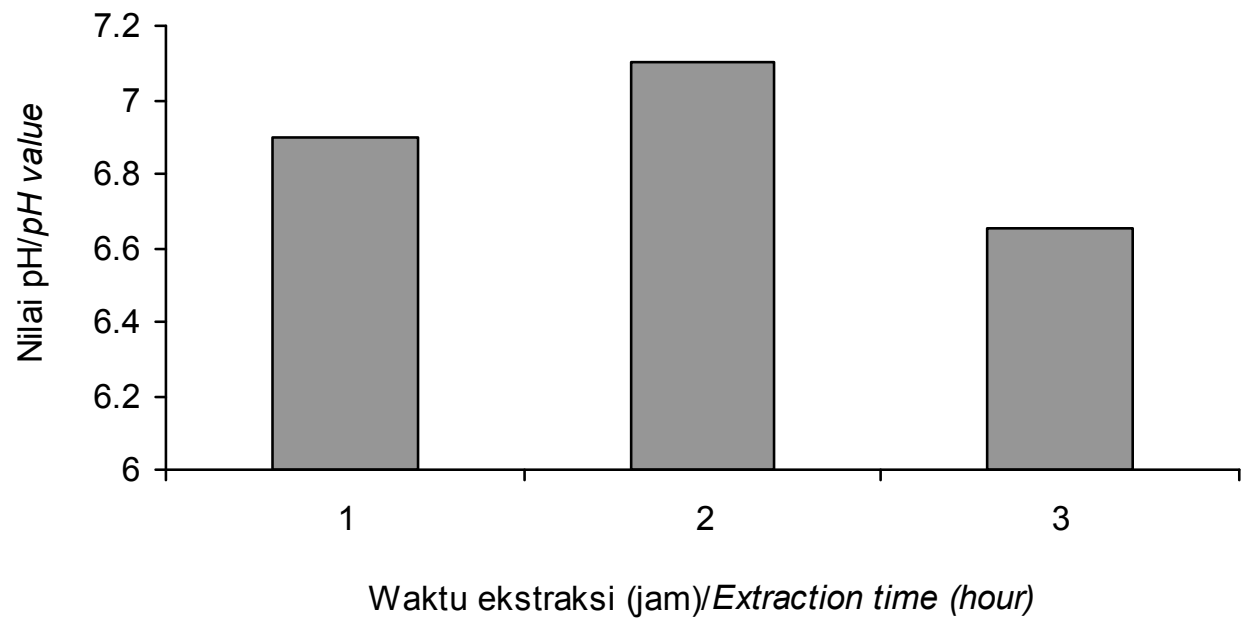

Gambar 8. Pengaruh waktu ekstraksi terhadap nilai pH bakto agar.

Figure 8. Effect of extraction time on $\mathrm{pH}$ value of bacto agar. 
bakto agar yang diperoleh pada proses ekstraksi selama 1, 2, dan 3 jam berturut-turut adalah 6,65; 7,10; dan 6,90.

Semua perlakuan waktu ekstraksi berpengaruh nyata terhadap $\mathrm{pH}$ bakto agar. Nilai $\mathrm{pH}$ yang berbeda diduga karena dipengaruhi oleh kadar 3,6 anhidrogalaktosa pada bakto agar yang tercermin dari kekuatan gel bakto agar (Gambar 7). Bila kadar 3,6 anhidrogalaktosa semakin rendah maka pHnya akan semakin rendah.

Nilai pH merupakan nilai yang menunjukkan derajat keasaman suatu bahan. Berdasarkan standar supreme marine chemical, nilai pH untuk bakto agar dengan grade standar dan premium adalah $6,8-7,5$, sehingga bakto agar yang memenuhi standar adalah bakto agar yang diekstraksi selama 2 dan 3 jam.

\section{Titik jendal}

Titik jendal bakto agar yang dihasilkan berkisar antara $25-34^{\circ} \mathrm{C}$. Titik jendal bakto agar dengan waktu ekstraksi 3 jam memberikan perbedaan yang nyata dibandingkan dengan waktu ekstraksi 1 dan 2 jam, sedangkan waktu ekstraksi selama 1 dan 2 jam tidak memberikan pengaruh yang nyata. Titik jendal tertinggi diperoleh dari proses ekstraksi selama 2 jam yaitu sebesar $34^{\circ} \mathrm{C}$ dan titik jendal terendah diperoleh dari proses ekstraksi selama 3 jam yaitu sebesar $25^{\circ} \mathrm{C}$ (Gambar 9).

Titik jendal adalah adalah suhu ketika terjadi pembentukan gel. Pembentukan gel adalah suatu fenomena penggabungan silang rantai-rantai polimer, sehingga membentuk suatu jala tiga dimensi yang bersambungan. Selanjutnya jala ini dapat menangkap atau mengimobilisasikan air di dalamnya dan membentuk struktur yang kuat dan kaku.
Bila dibandingkan dengan bakto agar komersial maka nilai titik jendal bakto agar yang dihasilkan dengan semua perlakuan masih di bawah standar bakto agar komersial. Bakto agar komersial memiliki standar nilai titik jendal berkisar antara $38-41^{\circ} \mathrm{C}$.

Rendahnya titik jendal pada penelitian ini disebabkan karena kadar sulfat bakto agar hasil ekstraksi $(3,6 \%)$ lebih tinggi dibandingkan dengan bakto agar komersial $(1,78)$. Purnawati (1992) menerangkan bahwa titik jendal erat kaitannya dengan kadar 3,6-anhidro-L-galaktosa dan sulfat. Apabila kadarnya tinggi akan menyebabkan sifat beraturan dalam rantai polimer bertambah sehingga meningkatkan potensi pembentukan heliks rangkap yang menyebabkan titik jendal akan lebih cepat tercapai. Ester sulfat pada atom karbon keenam dari L-galaktosa (C6) menyebabkan rantai polimer membentuk suatu tekukan yang dapat menghambat proses pembentukan gel (Glicksman, 1983).

\section{Titik leleh}

Titik leleh gel bakto agar yang dihasilkan berkisar antara $67-77^{\circ} \mathrm{C}$. Waktu ekstraksi berpengaruh nyata terhadap titik leleh bakto agar. Titik leleh tertinggi diperoleh dari waktu ekstraksi selama 2 jam yaitu $77^{\circ} \mathrm{C}$ dan titik leleh terendah diperoleh dari waktu ekstraksi selama 3 jam yaitu sebesar $67^{\circ} \mathrm{C}$ (Gambar 10).

Bila dibandingkan dengan bakto agar komersial maka titik leleh bakto agar yang dihasilkan dari semua perlakuan memiliki nilai di bawah standar bakto agar komersial. Bakto agar komersial memiliki standar nilai berkisar antara $78-80^{\circ} \mathrm{C}$. Rendahnya titik leleh bakto agar hasil penelitian ini diduga karena bobot molekul agar yang rendah. Menurut Glicksman (1983), bobot molekul dan ikatan hidrogen dalam suatu bahan mempengaruhi titik leleh. Bila bobot molekul suatu

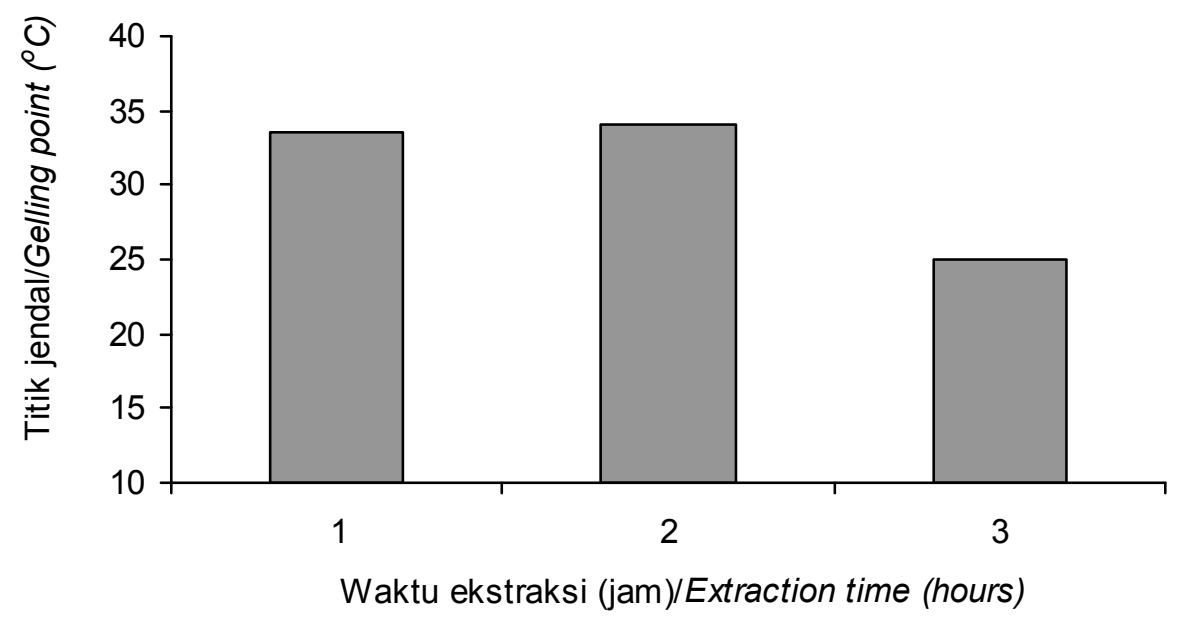

Gambar 9. Pengaruh waktu ekstraksi terhadap titik jendal bakto agar. Figure 9. Effect of extraction time on the gelling point of bacto agar. 


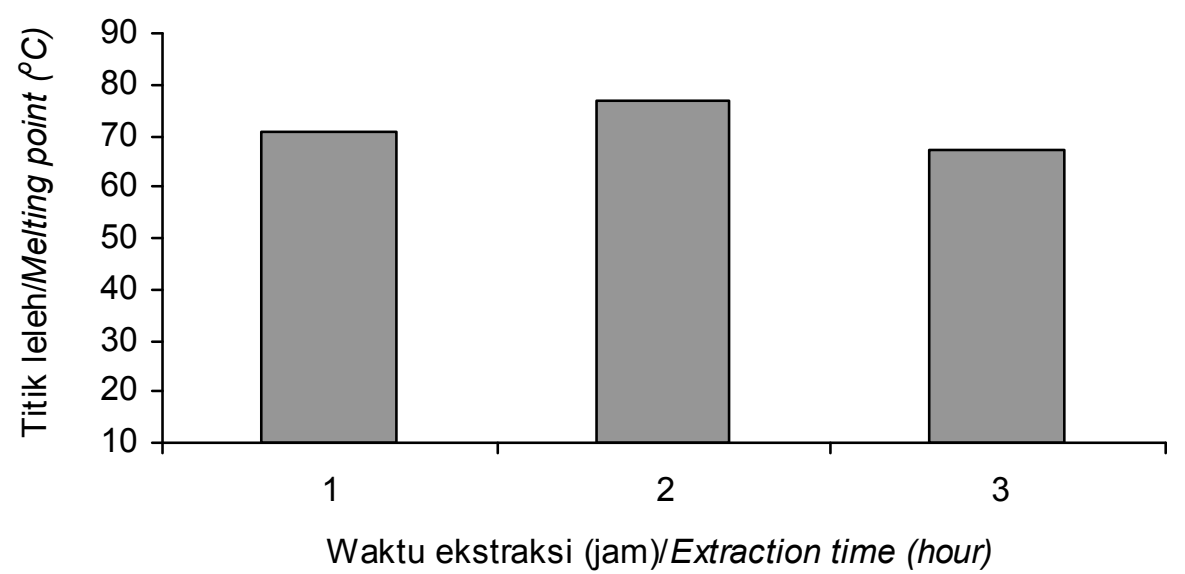

Gambar 10. Pengaruh waktu ekstraksi terhadap titik leleh bakto agar.

Figure 10. Effect of extraction time on the melting point of bacto agar.

bahan tinggi akan menyebabkan titik leleh juga tinggi, begitu pula sebaliknya.

Menurut Subaryono et al. (2003) titik leleh gel bukan merupakan faktor yang langsung mencerminkan kualitas agar, namun untuk memudahkan penggunaannya di lapangan, rentang suhu yang tinggi antara suhu pembentukan gel dan suhu pelelehan gel biasanya lebih dikehendaki.

\section{Uji mikrobiologi}

Uji mikrobiologi dilakukan untuk melihat kemampuan bakto agar khususnya kemampuannya dalam menumbuhkan bakteri ketika digunakan bersama komponen media pertumbuhan lainnya. Media bakto agar ini digunakan untuk menumbuhkan bakteri yang terdapat pada ikan serta kultur murni bakteri E. coli (monokultur Gram negatif) dan L. lactis (monokultur Gram positif). Uji mikrobiologi dilakukan pada bakto agar yang diekstraksi selama 2 jam dan hasilnya dapat dilihat pada Tabel 2.

Pada bakteri uji E.coli, nilai ALT bakto agar hasil ekstraksi adalah $2,7 \times 10^{8} \mathrm{cfu} / \mathrm{mL}$ sedangkan untuk bakto agar komersial $\mathrm{K} 1$ dan $\mathrm{K} 2$ sebesar 2,6 $\times 10^{8}$ $\mathrm{cfu} / \mathrm{mL}$ yang berarti bahwa nilai ALT bakto agar hasil ekstraksi sama dengan bakto agar komersial. Hal ini menunjukkan bahwa kemampuan bakto agar hasil

Tabel 2. Hasil uji mikrobiologi bakto agar

Table 2. Result of microbiological assesment of bacto agar

\begin{tabular}{llcc}
\hline & $\begin{array}{c}\text { Bakto agar hasil ekstraksi/ } \\
\text { Bacto agar produced made } \\
\text { these experiments }\end{array}$ & \multicolumn{2}{c}{$\begin{array}{c}\text { Bakto agar komersial/ } \\
\text { Commercial bacto agar }\end{array}$} \\
\cline { 5 - 5 } & & K1 & K2 \\
\hline 1. E. coli (Gram negatif) & $2.7 \times 10^{8}$ & $2.6 \times 10^{8}$ & $2.6 \times 10^{8}$ \\
\hline $\begin{array}{l}\text { Angka Lempeng Total (ALT)/Total Plate } \\
\text { Count (TPC) (cfu/mL) }\end{array}$ & $0.1-2.5$ & $0.1-3.2$ & 0.1 \\
\hline Diameter koloni/Colony diameter (mm) & & & \\
\hline 2. L. lactis (Gram positif) & $8.9 \times 10^{6}$ & $1.0 \times 10^{7}$ & $9.8 \times 10^{6}$ \\
\hline $\begin{array}{l}\text { Angka Lempeng Total (ALT)/Total Plate } \\
\text { Count (TPC) (cfu/mL) }\end{array}$ & $0.1-3.2$ & $0.1-7.2$ & $0.1-5.1$ \\
\hline $\begin{array}{l}\text { Diameter koloni/Colony diameter (mm) } \\
\text { 3. Ikan segar/Fresh fish }\end{array}$ & $3.1 \times 10^{9}$ & $2.3 \times 10^{9}$ & $7.4 \times 10^{8}$ \\
\hline $\begin{array}{l}\text { Angka Lempeng Total (ALT)/Total Plate } \\
\text { Count (TPC) (cfu/mL) }\end{array}$ & $0.3-6.0$ & $0.3-6.0$ & $0.3-6.0$ \\
\hline Diameter koloni/Colony diameter (mm)
\end{tabular}

Keterangan/Note: K1 : Bakto agar komersial merk 1/Commercial bacto agar brand 1 K2 : Bakto agar komersial merk 2/Commercial bacto agar brand 2 
ekstraksi dalam menumbuhkan bakteri $E$. coli sama dengan bakto agar komersial. Nilai diameter koloni untuk bakto agar hasil ekstraksi adalah 0,1-2,5 mm sedangkan diameter koloni bakto agar komersial K1 adalah 0,1-3,2 mm dan $\mathrm{K} 2$ adalah $0,1 \mathrm{~mm}$.

Pada bakteri uji $L$. lactis, nilai ALT bakto agar hasil ekstraksi adalah $8,9 \times 10^{6} \mathrm{cfu} / \mathrm{mL}$ sedangkan untuk bakto agar komersial K1 sebesar $1,0 \times 10^{7} \mathrm{cfu} / \mathrm{mL}$ dan K2 sebesar $9,8 \times 10^{6} \mathrm{cfu} / \mathrm{mL}$. Nilai ALT bakto agar hasil ekstraksi hampir sama dengan bakto agar komersial K2 dan lebih kecil dari K1. Hal ini menunjukkan bahwa kemampuan bakto agar komersial K1 dalam menumbuhkan bakteri L. lactis lebih besar daripada bakto agar hasil ekstraksi. Nilai diameter koloni untuk bakto agar hasil ekstraksi adalah $0,1-3,2 \mathrm{~mm}$ sedangkan diameter koloni bakto agar komersial K1 adalah 0,1-7,2 mm dan K2 adalah $0,1-5,1 \mathrm{~mm}$.

Pada ikan segar, nilai ALT bakto agar hasil ekstraksi adalah $3,1 \times 10^{9} \mathrm{cfu} / \mathrm{mL}$ sedangkan untuk bakto agar komersial $\mathrm{K} 1$ sebesar $2,3 \times 10^{9} \mathrm{cfu} / \mathrm{mL}$ dan $\mathrm{K} 2$ sebesar $7,4 \times 10^{8} \mathrm{cfu} / \mathrm{mL}$. Hal ini menunjukkan bahwa kemampuan bakto agar hasil ekstraksi dalam menumbuhkan bakteri lebih besar daripada bakto agar komersial K1 dan lebih kecil daripada bakto agar komersial K2. Nilai diameter koloni untuk bakto agar hasil ekstraksi adalah 0,3-6,0 mm sedangkan diameter koloni bakto agar komersial K1 dan K2 adalah 0,3-6,0 mm.

\section{KESIMPULAN}

Perlakuan waktu ekstraksi berpengaruh terhadap besarnya rendemen dan kualitas bakto agar yang diekstrak dari rumput laut Gelidium rigidum. Waktu ekstraksi selama 2 jam menghasilkan bakto agar yang mutunya memenuhi standar bakto agar komersial dari segi kadar air, pH, kadar abu, kadar abu tak larut asam, kekuatan gel, dan kemampuannya menumbuhkan bakteri yang terdapat pada ikan segar maupun kultur murni yaitu E. coli dan L. lactis tetapi belum memenuhi standar kadar sulfat, titik leleh, dan titik jendal yang dipersyaratkan.

\section{DAFTAR PUSTAKA}

Anonim. 2006. Cara Uji Mikrobiologi-Bagian 3 Penentuan Angka Lempeng Total (ALT) pada Produk Perikanan. Badan Standardisasi Nasional. 8 pp

Amnidar. 1989. Mempelajari Pengaruh Konsentrasi $\mathrm{NaOH}$ dan Waktu pada Perlakuan Alkali terhadap Mutu Agar-agar dari Rumput Laut Gracilaria verucosa. Skripsi. Fakultas Teknologi Pertanian IPB, Bogor. 70 pp.

Anonim. 1991. Prosiding Temu Karya IImiah Teknologi Pasca Panen Rumput Laut, 11-12 Maret. Buku II. Pusat
Penelitian dan Pengembangan Perikanan, Jakarta. $172 \mathrm{pp}$.

Anonymous. 2004. Supreme marine chemicals. http:// geocities.com/agar-agar/Supreme.html. Diakses tanggal 10 Mei 2004.

Anonymous. 2007a. Agars. http://bd.com/ds/technical centre/inserts/agars.pdf. Diakses tanggal 28 Agustus 2007.

Anonymous. 2007b. Agar in training manual on Gracilaria culture and seaweed processing in China. FAO Corporate Document. http://fao.org/docrep/field/003/ $A B 730 E / A B 730 E 00$. htm. Diakses tanggal 2 Desember 2007.

AOAC. 1984. Official Methods of Analysis of the Association of Official Analytical Chemists. 14 ed th A.O.A.C., Inc., Arlington, Virginia.

Apriyantono, A., Fardiaz, D., Puspitasari, N.L., Sedarnawati, dan Budianto. 1989. Analisis Pangan. Pusat Antar Universitas Pangan dan Gizi, IPB, Bogor. 229 pp.

Basmal, J., Syarifudin, dan Ma'ruf, W.F. 2003. Pengaruh konsentrasi larutan potasium hidroksida terhadap mutu kappa-karaginan yang diekstraksi dari Eucheuma cottonii. J. Penel. Perik. Indonesia. 9(5): 95-103.

Glicksman, M. 1983. Food Hydrocolloids. Vol. II. CRC Press. Inc. Boca Raton, Florida. 199 pp.

Murdinah, Amini, S., Irianto, H.E., Peranginangin, R., Subaryono, Darmawan, M., Sinurat, E., dan Fransiska, D. 2006. Optimasi pemanfaatan makro dan mikro alga. Laporan Teknis. Balai Besar Riset Pengolahan Produk dan Bioteknologi Kelautan dan Perikanan, Jakarta. 89 pp.

Purnawati, D.W. 1992. Pengaruh Perbandingan Rumput Laut Gracilaria verucosa dan Gelidium rigidum Terhadap Mutu Agar-Agar Kertas. Skripsi. Fakultas Teknologi Pertanian, IPB, Bogor. 84 pp.

Steel, R.G.D and Torrie, J.H. 1993. Prinsip dan Prosedur Statistika, Suatu Pendekatan Biometrik. Alih Bahasa B. Soemantri. PT Gramedia Pustaka Utama. Jakarta. p. 377-398.

Subaryono, Utomo, B.S.B., Wikanta, T., dan Satriyana, N. 2003. Pengaruh penambahan biota karaginan pada ekstraksi agarosa dari agar-agar menggunakan Cetyl piridinium chloride. J. Penel. Perik. Indonesia. 9(5): $1-9$.

Selby, H.H. and Wynne, W.H. 1973. Agar. In R.L Whistler and BeMiller, J.M. (eds.). Industrial Gums. Academic Press, New York, 807 pp.

Stanley. N. 1987. Production, properties and uses of carageenan. In Mc Hugh, D.J. (ed.). Production and utilization of products from commercial seaweeds. FAO Fish Tech Paper. 288: 116-146.

Suryaningrum, T.D., Murtini, J.T., Wibowo, S., dan Suherman, M. 1994. Kajian sifat fisik dan organoleptik tepung agar-agar dari rumput laut Gracilaria tambak. J. Penel. Perik. Indonesia. 83: 1-12.

Utomo, B.S.B., Nasran, S., Priono, B., dan Sukamulyo, S. 1990. Pengolahan agar-agar kertas dari rumput laut Gelidium rigidum. J. Penel. Perik. Indonesia. 65: 31-40. 